\title{
ORGANISASI SOSIAL PADA MASYARAKAT GIRI JAYA PADEPOKAN DESA GIRI JAYA KECAMATAN CIDAHU KABUPATEN SUKABUMI
}

\author{
Oleh Ria Andayani Somantri \\ Balai Pelestarian Sejarah dan Nilai Tradisional Bandung \\ Jln. Cinambo No. 136 Ujungberung Bandung \\ Email: riaandayanisomantri @yahoo.com \\ Naskah diterima: 24 Juni 2010 \\ Naskah disetujui: 6 Setember 2010
}

\begin{abstract}
Abstrak
Penelitian tentang organisasi sosial pada masyarakat Giri Jaya Padepokan di Kabupaten Sukabumi bertujuan untuk mengetahui dasar-dasar pembentukan dan struktur organisasi sosial pada masyarakat tersebut. Metode penelitian yang digunakan bersifat deskripsi, dengan pendekatan kualitatif melalui teknik pengumpulan data berupa wawancara dan pengamatan. Dari penelitian tersebut diperoleh gambaran bahwa organisasi sosial pada masyarakat Giri Jaya Padepokan mengacu pada satu tatanan lama warisan leluhur atau lembaga adat yang masih digunakan sampai saat ini. Sekalipun tidak ada nama lokal bagi lembaga adat tersebut, struktur lembaga adatnya cukup jelas dan sederhana. Struktur lembaga adat itu terdiri atas ketua adat, sesepuh adat (wakil ketua adat, juru kunci, amil, tokoh seni, tokoh agama, paraji, koordinator warga, dan tokoh masyarakat), serta warga Giri Jaya Padepokan yang disebut jamaah.
\end{abstract}

Kata kunci: organisasi sosial.

\begin{abstract}
This paper is about social organization of the community of Giri Jaya Padepokan in Sukabumi. The aim of the study is to examine some basis for the function of the structure of social organization in the community. The author used descriptive method and qualitative approach. Data were collected through interviews and observations. The author came into conclusion that the community of Giri Jaya Padepokan is still preserving the structure of social organization inherited from their ancestors. The institutions in question are ketua adat (the chief), sesepuh adat (the elders), juru kunci (the locksmith), amil (a person who collects charity for religious purposes), and other public figures such as art and political figures, paraji (midwives), a coordinator for people, and the people of Giri Jaya Padepokan itself called jamaah.
\end{abstract}

Keywords: social organization.

\section{A. PENDAHULUAN}

Pada era reformasi, Indonesia mengalami perubahan penting dalam paradigma sistem politik, terutama dalam sistem pemerintahannya. Dalam hal ini terjadi perubahan dari paradigma pemerintahan yang terpusat (centralized) ke paradigma pemerintahan yang lebih memberikan peran pada pemerintah daerah 
(decentralized). Paradigma semacam itu, menuntut adanya pemerintahan daerah yang lebih kuat serta lebih mampu menjalankan peran-peran pemerintahan.

Kekuatan pemerintahan daerah akan sangat terbantu jika ada organisasi-organisasi sosial lokal tradisonal yang masih aktif mengelola berbagai masalah kemasyarakatan. Organisasi sosial sendiri adalah polapola hubungan antar-individu dan kelompok masyarakat, yang timbul dalam proses interaksi social (Soekanto, 1983:52). Adapun organisasi sosial lokal tradisional adalah organisasi sosial dalam suatu kelompok masyarakat, yang tampak khas sifatnya dan diwariskan dari generasi ke generasi selama puluhan bahkan ratusan tahun.

Sampai saat ini, ada banyak organisasi sosial lokal tradisional yang masih bertahan, sekalipun selama bertahun-tahun pada masa Orde Baru telah diberlakukan undang-undang baru dalam sistem pemerintahan desa. Oleh karena itu, dipandang perlu melakukan penelitian terhadap keberadaan organisasi sosial pada berbagai kelompok masyarakat, salah satunya pada masyarakat Giri Jaya Padepokan di Kabupaten Sukabumi, Provinsi Jawa Barat.

Penelitian tersebut berjudul Organisasi Sosial pada Masyarakat Giri Jaya Padepokan di Kabupaten Sukabumi, dengan masalah penelitiannya berupa pertanyaaan, yakni "Apakah dasar pembentukan organisasi sosial pada masyarakat Giri Jaya Padepokan di Kabupaten Sukabumi?" dan "Bagaimanakah struktur organisasi sosial pada masyarakat Giri Jaya Padepokan di Kabupaten Sukabumi?'. Adapun tujuan penelitian tersebut adalah untuk mengetahui dasar-dasar pembentukan organisasi sosial tadi serta struktur organisasi sosialnya. Ruang lingkup penelitian meliputi ruang lingkup wilayah, yakni di wilayah Giri Jaya Padepokan, yang mencakup Giri Jaya Pusat, Giri Jaya Tengah, dan Giri Jaya Hilir; dan ruang lingkup materi mencakup gambaran umum Desa Giri Jaya, dasar pembentukan organisasi sosial, serta struktur organisasi sosial.

Metode penelitian yang digunakan bersifat deskripsi atau menggambarkan. Penelitian deskriptif bertujuan menggambarkan secara tepat sifat-sifat suatu gejala sosial, baik individu-individu, kelompok-kelompok, dan keadaan sosial tertentu. Oleh karena itu, pendekatan yang sesuai untuk jenis penelitian deskriptif adalah pendekatan kualitatif, dengan teknik pengumpulan data yang digunakan di lapangan adalah pengamatan dan wawancara.

\section{B. HASIL DAN BAHASAN}

Dikisahkan kurang lebih pada tahun 1827, ada seorang laki-laki bertapa di kaki Gunung Salak sebelah selatan, pada ketinggian 900 meter dari permukaan laut. Konon, dia berasal dari Surakarta dan bernama Eyang Abu Soleh atau versi lain menyebutnya Eyang Abu Sholih, serta sering menyebut dirinya Eyang Kulon. Dia bertapa memohon kepada sang pencipta alam semesta raya agar masyarakat yang sedang dijajah Belanda pada masa itu diberi keselamatan. Dia bertahan di tempat 
tersebut selama hampir tiga setengah tahun.

Pada suatu ketika, seseorang dari Mangku Negara Surakarta, yang menamakan dirinya Eyang Wetan atau Ama Santri datang ke kaki Gunung Salak. Dia bertemu dan kemudian bersahabat dengan Eyang Kulon. Dia mengajak Eyang Kulon pindah ke arah bawah dari kaki Gunung Salak sejauh satu kilometer. Pada tahun 1830, Eyang Kulon mulai membuka lahan tersebut dan menamakannya Giri Jaya Pondok Gusti.

Nama Giri Jaya Pondok Gusti dimaknai sebagai berikut: Giri berarti gunung, karena berada di kaki Gunung Salak; Jaya merupakan tawasulan 'harapan' agar masyarakat di tempat tersebut selalu berada dalam kejayaan, baik lahir maupun batin; Pondok merupakan isyarat yang menunjukkan dia sudah mulai menetap setelah sekian lama bertapa di kaki Gunung Salak; adapun Gusti diperkirakan merupakan identitas dirinya sebagai salah seorang raja, yang lazim disebut gusti. Persahabatan tersebut juga diabadikan dengan menanam dua pohon jambu samarang kira-kira pada 1831. Sampai saat ini, pohon tersebut masih berdiri kokoh dan dirawat oleh keturunan mereka.

Eyang Kulon membangun rumah besar yang disebut imah kidul. Di rumah itu pula lahir 5 orang anaknya, yakni Muhamad Kentar, R Wiratmaja, R. Bai, R. Anjung, dan Ra. Ningrum. Sejak tinggal di rumah itu, dia sering dikunjungi banyak orang yang ingin meminta syariat keberkahan kepadanya, karena namanya dikenal sebagai seorang kyai. Selain itu, dia pun masih melanjutkan kebiasaannya bertapa. Kebiasaan tersebut menurun pada salah satu cucunya, RD. Dadang, putra R. Wiratmaja. Sejak umur 6 tahun, anak tersebut bertapa di sejumlah pasir 'bukit', kebun, juga di makam Eyang Wetan atau Ama Santri yang meninggal pada 1929.

Suatu ketika, Eyang Kulon menyuruh RD. Dadang yang baru berusia 7 untuk mandi dan mengenakan bendo 'tutup kepala', kemeja, serta kain. Selanjutnya, dia meminta cucunya memainkan wayang golek untuk menghibur warga masyarakat dan para tamu yang datang ke tempat tersebut. Ajaib, dia mampu melakukannya dengan baik, padahal dia tidak pernah belajar menjadi dalang. Tampaknya, saat itu perasaan dan jiwa Eyang Kulon merasuk ke dalam jiwa cucunya. Sejak saat itu, RD Dadang populer dengan sebutan dalang cilik dan banyak mendapat undangan tampil di berbagai daerah.

Pada 1942, Eyang Kulon wafat dan tampuk pimpinan diteruskan oleh salah satu anak laki-lakinya, yakni Eyang Wiratmaja. Begitu juga ketika Eyang Wiratmaja meninggal pada 1964, salah satu anak laki-lakinya, yakni RD Dadang menjadi penggantinya. RD. Dadang sendiri mempunyai dua orang putra bernama RD. N. Ruyat dan R.Darma. Pada masa dia menjadi ketua adat Giri Jaya Pondok Gusti, beberapa kegiatan besar dilaksanakan, seperti melaksanakan upacara seren taun nampa taun setiap tahun; menambah kegiatan khitanan massal pada acara muludan; mengajak warga masyarakat membangun jalan dari Giri Jaya sampai Cibaregbe, melalui pengerasan jalan sepanjang 3 $\mathrm{km}$ antara Giri Jaya dan Jabon sehingga kendaraan bisa sampai ke Girijaya; dan menambah bangunan pada imah kidul 
berupa pendopo, dapur umum, ruang penginapan tamu, dan merapikan halaman.

RD. Dadang meninggal pada tahun 1987. Tampuk pimpinan Giri Jaya jatuh pada salah satu anaknya, yaitu RD.N Ruyat. Dia meneruskan tradisi warisan leluhurnya, bahkan mendapat dukungan lebih besar dari masyarakat setempat dan di luar itu, seperti dari Sukabumi, Bogor, Bekasi, dan Tangerang. Dia juga mengubah Giri Jaya Pondok Gusti menjadi Padepokan Giri Jaya. Nama padepokan digunakan karena beberapa alasan. Pertama, masyarakatnya masih memelihara tradisi leluhur, terutama kesenian tradisional, seperti wayang golek, kacapian, dan degung. Selain itu, tempat tersebut juga merupakan tempat jamaah atau keluarga besar Giri Jaya bersilaturahim pada saat muludan dan Idul Fitri.

Setelah 2 hingga 3 tahun berjalan, perubahan tersebut dianggap kurang membawa berkah bagi masyarakat setempat juga keluarga besar Giri Jaya. Setelah berdoa kepada Yang Mahakuasa, akhirnya dia mendapat petunjuk agar mengganti nama Padepokan Giri Jaya menjadi Giri Jaya Padepokan.

Kini, nama Giri Jaya Padepokan menunjuk pada satu kawasan yang dihuni oleh sekelompok masyarakat yang memegang teguh adat istiadat Giri Jaya Padepokan. Wilayah Giri Jaya Padepokan terdapat di Dusun Giri Jaya atau di RW 04, Desa Giri Jaya, Kecamatan Cidahu, Kabupaten Sukabumi, Provinsi Jawa Barat. Lokasinya sekitar $128 \mathrm{~km}$ dari ibu kota Provinsi Jawa Barat, di Kota Bandung. Secara adat, wilayah Giri Jaya
Padepokan dibagi menjadi Giri Jaya I atau Giri Jaya Pusat yang juga merupakan lingkungan karamat, mencakup RT 07 dan RT 09 dengan 117 rumah di dalamnya; Giri Jaya II atau Giri Jaya Tengah, yang mencakup RT 08 dan sebagian RT 04 dengan 110 rumah di dalamnya; dan Giri Jaya III atau Giri Jaya Hilir, yang mencakup sebagian RT 04 dan RT 05 dengan 75 rumah di dalamnya. Selain itu, masih banyak keturunan Giri Jaya Padepokan yang tinggal di luar ketiga wilayah adat tadi. Mereka beragama Islam dan umumnya memilki mata pencaharian sebagai petani.

Sistem organisasi sosial masyarakat Giri Jaya Padepokan mengacu pada suatu lembaga adat yang mengatur kedudukan warga dalam struktur masyarakat setempat. Tak ada nama khusus yang diberikan terhadap lembaga adat tersebut, namun struktur organisasinya cukup sederhana dan mudah untuk dipahami. Dalam struktur lembaga adat tersebut terdapat ketua adat, para sesepuh, dan keluarga besar Giri Jaya Padepokan yang disebut jamaah.

\section{Ketua Adat}

Ketua adat menempati kedudukan paling tinggi dalam struktur masyarakat Giri Jaya Padepokan. Secara otomatis, orang yang berada pada kedudukan tersebut merupakan pemimpin di Giri Jaya Padepokan. Dia kerap disapa dengan sebutan abah oleh warga Giri Jaya Padepokan. Tidak mudah dan tidak sembarang orang bisa mendapatkan posisi sebagai orang nomor satu di tempat tersebut. Ada sejumlah persyaratan yang harus dipenuhi. Gambaran mengenai ketua adat Giri Jaya Padepokan tampak 
melalui uraian menyangkut figur, kewajiban, dan hak ketua adat.

\section{a. Figur Ketua Adat}

Hak untuk menjadi ketua adat dipegang oleh keturunan cikal bakal masyarakat Giri Jaya Padepokan, yakni Eyang Abu Sholih atau Eyang Abu Soleh. Sampai saat ini, tercatat sudah berlangsung empat generasi kepemimpinan, dengan nama ketua adatnya secara berurutan adalah Eyang Abu Sholih, Eyang Wiratmaja, RD Dadang, dan RD. N. Ruyat. Keempat ketua adat tersebut laki-laki. Itu artinya, tampuk pimpinan biasanya jatuh pada anak laki-laki dari pemimpin sebelumnya.

Jika hanya ada satu anak lakilaki, proses penggantian ketua adat tidak akan memakan waktu lama. Sebaliknya jika ketua adat meninggalkan lebih dari satu anak laki-laki, biasanya akan ada proses pencarian calon ketua adat dalam waktu yang tidak dapat dipastikan lamanya. Proses pencarian seperti itu tergambar pada masa penggantian ketua adat generasi ketiga, yang wafat pada 1987. Dia memiliki lebih dari satu anak laki-laki sehingga tidak mungkin bisa langsung mengangkat seorang ketua adat yang baru. Untuk memunculkan calonnya, diperlukan suatu proses pemilihan yang berlangsung sejak saat itu. Peran masyarakat cukup nyata dalam mencari dan menemukan calon ketua adat yang sesuai dengan harapan mereka.

Warga Giri Jaya Padepokan mengharapkan calon ketua adat mereka memiliki hati yang ikhlas dan sabar dalam memenuhi kebutuhan batin mereka; rela berkorban jiwa dan raga, serta lebih mengutamakan kepentingan umum daripada kepentingan pribadi, karena setiap saat dia harus menerima dan melayani jamaah atau keluarga besar Giri Jaya Padepokan dan tamu yang mengunjunginya; memiliki sifat dermawan, karena dia kerapkali dihadapkan pada berbagai kesulitan ekonomi yang dihadapi warganya; dan tentu saja menguasai secara mendalam adat istiadat masyarakat Giri Jaya Padepokan.

Satu persatu anak laki-laki dari ketua adat yang lama dikunjungi warga yang ingin memenuhi kebutuhan batin mereka. Jika ada kecocokan dengan salah satu di antara calon-calon tadi, beritanya akan sampai dari satu warga ke warga lainnya. Dari kunjungankunjungan tersebut, pada akhirnya mereka menemukan calon ketua adat yang sesuai dengan harapan mereka. Kondisi seperti itu ditandai dengan kecenderungan warga untuk selalu mendatangi orang yang sama bagi pemenuhan kebutuhan batin mereka.

Masyarakat juga merasa yakin, leluhur akan turun tangan menunjukkan jalan yang terbaik untuk masalah tersebut. Petunjuk seperti itu kerap disebut wangsit, yang disampaikan melalui mimpi. Wangsit yang sama biasanya datang kepada para sesepuh komunitas adat Giri Jaya Padepokan, dalam rentang waktu yang relatif berdekatan. Apa yang dimimpikan mereka tidak akan jauh berbeda dengan apa yang dirasakan masyarakat. Kesesuaian antara pendapat masyarakat dan wangsit leluhur merupakan landasan yang kuat untuk kembali mengangkat ketua adat yang baru.

Langkah berikutnya adalah melegitimasi calon ketua adat menjadi ketua adat sesungguhnya yang sah menurut adat akan memimpin komunitas adat Giri Jaya Padepokan. Legitimasi 
biasanya dilakukan pada acara-acara adat yang dihadiri banyak orang, seperti upacara seren taun nampa taun, pertemuan rutin malam Jumat Kliwon, dan upacara muludan. Pilihan waktu pengukuhan bergantung pada kedekatan waktu acara pengukuhan terhadap acara adat yang akan diselenggarakan. Pada acara adat yang dihadiri jamaah Giri Jaya Padepokan itulah, diumumkan dan diperkenalkan ketua adat yang baru.

Perjalanan untuk menemukan pemimpin baru seperti yang terjadi pada penggantian ketua adat generasi ketiga oleh generasi keempat memakan waktu yang cukup lama. Tiga tahun lamanya warga masyarakat dan para sesepuh menjalani proses itu, yakni dari 1987 sampai dengan 1990. Sejak 1991 itulah, ketua adat generasi keempat secara resmi memimpin Giri Jaya Padepokan. Masa jabatan itu kelak akan berakhir pada saat dia meninggal.

\section{b. Kewajiban Ketua Adat}

Ada sejumlah kewajiban yang harus dilaksanakan oleh seorang ketua adat. Sekalipun kewajiban itu tidak diatur secara tegas dan tertulis, namun disadari sepenuhnya oleh yang bersangkutan dan warga Giri Jaya Padepokan. Oleh karena itu, ketua adat berupaya seoptimal mungkin melaksanakan kewajibannya dengan penuh tanggung jawab. Dua kewajiban utama yang menjadi tanggung jawabnya adalah kewajban yang bersifat pribadi dan kewajiban yang bersifat umum.

\section{1) Kewajiban yang Bersifat Pribadi}

Pertama, ketua adat berkewajiban melaksanakan syukuran kepada Allah SWT atas segala rahmat, kebahagiaan, dan kenikmatan yang dilimpahkan kepada dia dan warganya. Selain itu, dia berkewajiban untuk bersyukur atas berkah dari para leluhur Giri Jaya Padepokan. Entitas leluhur itu tidak dapat disebutkan satu persatu, namun dapat dikelompokkan sedemikian rupa.

Kelompok pertama, leluhur yang dipandang berjasa menyebarkan agama Islam, yakni agama yang dianut seluruh warga masyarakat Giri Jaya Padepokan. Yang termasuk ke dalam kelompok tersebut adalah Wali Songo, yang terdiri atas. Sunan Gresik atau Maulana Malik Ibrahim, Sunan Ampel atau Raden Rahmat, Sunan Bonang atau Raden Makhdum Ibrahim, Sunan Drajat atau Raden Qasim, Sunan Kudus atau Jaffar Shadiq, Sunan Giri atau Raden Paku atau Ainul Yaqin, Sunan Kalijaga atau Raden Said, Sunan Muria atau Raden Umar Said, dan Sunan Gunung Jati atau Syarif Hidayatullah.

Kelompok kedua, leluhur yang menghuni tempat-tempat di empat penjuru wilayah Giri Jaya Padepokan, yakni di sebelah utara, selatan, barat, dan timur; serta yang menghuni tempat-tempat di bagian tengah dan bawah wilayah tersebut.

Kelompok ketiga, leluhur yang telah berjasa melahirkan dan menyebabkan masyarakat Giri Jaya Padepokan ada sampai saat ini. Yang termasuk ke dalam kelompok tersebut adalah 8 generasi ke atas, yang terdiri atas sepuh 'orang tua', aki-nini 'kakeknenek', uyut 'orang tua dari kakeknenek', bao 'orang tua dari uyut', udegudeg 'orang tua dari bao', gantung siwur 'orang tua dari bao', jangga wareng 'orang tua dari gantung siwur', 
dan generasi terjauhnya adalah adam dan hawa.

Kewajiban ketua adat berikutnya adalah melakukan tawasul, yakni memohon kepada Allah SWT agar diberi umur panjang, badan yang sehat, rezeki yang cukup untuk memenuhi kebutuhan masing-masing juga untuk beribadah.

\section{2) Kewajiban yang Bersifat Umum}

\section{(a) Membantu Warga}

Seorang ketua adat harus mampu bertindak sebagai orang tua bagi warganya. Dia bisa menjadi tempat bersandar, berkeluh kesah, meminta perlindungan, dan pertolongan manakala warganya sedang menghadapi masalah, termasuk masalah ekonomi. Ketika ada warganya yang datang dengan kondisi seperti itu, dia memiliki kewajiban untuk ikut membantu menyelesaikan permasalahan yang sedang dihadapi warganya.

Bantuan yang diberikan tentu saja disesuaikan dengan permasalahan yang dihadapi warganya. Ada yang memang membutuhkan bantuan materi berupa uang atau barang; ada pula yang lebih memerlukan saran atau nasihat untuk menyelesaikan permasalahan mereka, baik yang berkaitan dengan masalah rumah tangga, pekerjaan, dan kegiatan bertani; dan ada pula yang mengharapkan doa keberkahan dari ketua adat agar segala niat baik melaksanakan sesuatu dapat berjalan lancar sesuai rencana.

\section{(b) Menjaga Lingkungan Karamat}

Seorang ketua adat memiliki kewajiban untuk menjaga lingkungan Giri Jaya Padepokan secara keseluruhan agar tampak bersih, nyaman, aman, sehat, dan memberikan manfaat yang positif bagi kehidupan warganya. Yang lebih penting lagi, dia juga harus mampu menjaga keberadaan lingkungan karamat. Keberadaan lingkungan karamat dalam kehidupan masyarakat Giri Jaya Padepokan sangat penting. Dari sanalah cikal bakal masyarakat Giri Jaya Padepokan memulai asal-usul kehidupan mereka sampai generasi yang sekarang. Sebagai wujud penghormatan kepada para leluhur, lingkungan tersebut masih dipertahankan dan dirawat dengan baik hingga sekarang. Bagaimanapun juga, keberadaan lingkungan karamat dengan segala isinya menjadi salah satu cermin jati diri masyarakat Giri Jaya Padepokan.

Lingkungan karamat merupakan wilayah Giri Jaya Padepokan yang paling istimewa dibandingkan dengan tempat lainnya secara keseluruhan. Area lingkungan karamat tak lain adalah wilayah Giri Jaya I atau Giri Jaya Pusat. Lokasinya terletak paling utara di wilayah Giri Jaya Padepokan. Untuk menuju lingkungan karamat, perjalanan akan bergerak dari arah selatan menuju utara.

Tiba di pertigaan, tepat di depan pintu gerbang menuju Pasarean Eyang Santri, ada arah yang lurus ke utara dan ada yang belok kiri ke arah barat. Arah ke utara merupakan jalan menuju Pasarean Eyang Santri, yang terletak paling utara dan menempati posisi yang paling tinggi. Lokasi tersebut merupakan bagian dari lingkungan karamat. Ada juga jalan alternatif menuju makam Eyang Santri, yakni harus belok ke arah barat, yang merupakan pintu gerbang masuk ke kawasan lingkungan karamat.

Di sepanjang kiri kanan jalan yang tidak terlalu panjang dan lebar itu 
berdiri sejumlah bangunan penting. Keberadaan bangunan tersebut sangat terkait erat dengan pelaksanaan adat istiadat di Giri Jaya Padepokan. Di sebelah kanan jalan terdapat beberapa bangunan yang tetap dipertahankan sejak dulu. Kalaupun bangunan tersebut tampak baru, tetap dianggap penting karena masih terkait dengan adat istiadat setempat. Posisi bangunan tidak berada pada satu dataran yang sama, melainkan bertingkat dari yang sejajar dengan jalan hingga dataran yang lebih tinggi.

Pada lapisan yang sejajar dengan jalan terdapat imah panjang 'rumah panjang', imah kaler 'rumah utara', kulah 'kolam', dan imah kolot 'rumah ketua adat'; pada lapisan kedua terdapat kamar mandi umum, imah kuncen 'rumah kuncen', prasasti Giri Jaya, dan tempat ngawirid atau ngaramat. Pada lapisan ketiga terdapat pasarean Giri Jaya serta mesjid; kemudian di lapisan terakhir atau paling puncak terdapat makam Eyang Santri. Dari lapisan pertama menuju lapisan berikutnya dihubungkan oleh undakan.

Di bagian kiri jalan juga terdapat sejumlah bangunan penting, dengan posisi yang juga tidak berada dalam satu dataran yang sama. Pada lapisan yang sejajar dengan jalan terdapat panggung, paseban, imah kidul 'rumah selatan', sebuah tempat berlatih kesenian, dan pos ronda. Selain itu, terdapat sepasang pohon jambu samarang. Sementara itu di dataran yang lebih rendah dari itu terdapat saung lisung 'saung lesung' dan leuit 'lumbung padi'.

Di dalam wilayah lingkungan karamat tidak hanya tersimpan ke- kayaan arsitektur tradisional bernuansa Jawa dan Sunda, juga tersimpan sejumlah benda-benda pusaka, seperti peralatan kesenian, keris, dan naskah kuna. Sebagian benda pusaka tersebut ditempatkan di bangunan-bangunan adat, seperti imah karuhun dan paseban; dan sebagian lagi disimpan di rumah ketua adat. Konon, sejumlah naskah kuna yang ada di tempat tersebut belum berhasil diterjemahkan isinya.

Sejak dulu sampai dengan saat ini, lingkungan karamat yang luasnya satu hektar itu menjadi pusat Giri Jaya Padepokan. Oleh karena itu, ketua adat Giri Jaya Padepokan menetap di lingkungan tersebut. Pelaksanaan berbagai aktivitas adat pun dipusatkan di lingkungan karamat, seperti penyelenggaraan upacara adat seren taun nampa taun, muludan, dan pertemuan rutin pada setiap malam Jumat Kliwon. Karena keberadaan lingkungan karamat sangat penting bagi kehidupan masyarakat Giri Jaya Padepokan, ketua adat memiliki kewajiban untuk menjaga dan melestarikan keberadaannya. Hal itu merupakan bentuk pertanggungjawaban dia sebagai ketua adat kepada leluhur dan keturunannya kelak.

\section{(c) Melestarikan Adat Istidat Giri Jaya Padepokan}

Pada dasarnya, seorang ketua adat dalam konteks kehidupan masyarakat Giri Jaya Padepokan merupakan perwakilan leluhur di dunia. Dia juga menjadi mediator bagi warganya yang ingin berkomunikasi dengan leluhur. Oleh karena itu, dia dipastikan memiliki pengetahuan yang luas dan mendalam tentang adat istiadat yang diwariskan leluhurnya. Segala sesuatu 
yang terkait dengan adat istadat Giri Jaya Padepokan menjadi tanggung jawabnya. Dia memiliki kewajiban untuk melestarikan adat istiadat yang dititipkan leluhur kepadanya. Yang lebih penting lagi adalah meneruskan adat istiadat tersebut kepada generasi berikutnya.

Adat istiadat Giri Jaya Padepokan yang harus dilestarikan oleh ketua adat adalah segala kebiasaan yang dulu dilakukan oleh leluhurnya. Sudah tentu, hal itu tidak bersifat statis namun dinamis. Perubahan dipastikan terjadi, selama itu merupakan kesepakatan bersama dan tidak melanggar aturan-aturan yang telah digariskan leluhurnya. Kalaupun ingin melakukan perubahan yang sangat mendasar, ketua adat akan melakukan ritual permohonan izin terlebih dulu kepada leluhur. Dengan izin leluhur, perubahan tadi diharapkan akan mendatangkan berkah bagi kehidupan warga Giri Jaya Padepokan.

Berkaitan dengan upaya menjaga kelestarian adat istiadat masyarakat Giri Jaya Padepokan, ketua adat melakukan beberapa upaya. Dia senantiasa membimbing warganya agar selalu patuh pada aturan yang telah ditetapkan leluhurnya, dan tidak melanggar apa yang ditabukan leluhurnya. Kalau ada di antara warganya yang keluar dari aturan adat setempat, dia akan mengingatkan dan menegurnya supaya kembali pada koridor adat sehingga dia senantiasa mendapat bekah dari leluhur. Kalaupun hal itu tetap tidak diindahkan, semuanya akan dikembalikan kepada yang bersangkutan. Dia tidak dapat memaksanya, apalagi sampai memberi sanksi atau hukuman kepada warga seperti itu.
Adat istiadat warisan leluhur tercermin dalam berbagai aspek kehidupan masyarakat Giri Jaya Padepokan, seperti dalam sistem mata pencaharian hidup, khususnya dalam aktivitas pertanian; dalam sistem kemasyarakatan, yang masih mengacu pada lembaga adat; dalam sistem religi, yang masih diwarnai dengan kepercayaan yang diwariskan leluhurnya; dalam aspek kesenian, yang masih begitu konsisten memelihara sejumlah kesenian tradisional; dan dalam sistem teknologi, yang di antaranya tampak pada sejumlah bangunan peninggalan leluhur, dan kekayaan kuliner yang biasa disajikan dalam upacara-upacara tradisional.

\section{c. Hak-hak Ketua Adat}

Seorang ketua adat tidak hanya dibebani dengan kewajiban, melainkan juga diberi hak-hak yang cukup istimewa. Pada dasarnya, adat tidak mengatur secara tegas hak-hak yang dimiliki seorang ketua adat. Meskipun demikian, hal itu disadari dan dilaksanakan sepenuhnya oleh ketua adat dan warganya dalam kehidupan seharihari. Beberapa hak istimewa tersebut adalah mengangkat para pejabat adat, memimpin kegiatan adat, dan menerima kunjungan keluarga besar Giri Jaya Padepokan atau jamaah.

\section{1) Menerima Jamaah}

Keluarga besar Giri Jaya Padepokan atau jamaah dan ketua adat merupakan satu kesatuan yang tidak terpisahkan dan saling memerlukan satu sama lainnya. Ketua adat sangat membutuhkan dukungan penuh dari jamaah agar kelangsungan adat istiadat Giri Jaya Padepokan terjaga selamanya. Sementara itu, jamaah memerlukan 
ketua adat untuk memenuhi berbagai kebutuhan batinnya agar senantiasa mnedapat keberkahan dalam kehidupannya. Oleh karena itu, komunikasi menjadi jalan untuk mempertemukan kedua kepentingan tersebut.

Ketika ketua adat memerlukan dukungan warganya terkait dengan aktivitas adat, hal itu akan sampai kepada mereka melalui perangkat adat yang dimilikinya. Artinya, bukan pada tempatnya bagi dia untuk langsung mendatangi warganya satu per satu.

Ketika jamaah memerlukan ketua adat untuk memenuhi kebutuhan batinnya, sudah tentu mereka akan datang sendiri menemuinya. Seperti itulah komunikasi yang terjalin di antara keduanya, berikut tatakrama mereka dalam berkomunikasi. Dalam hal ini, ketua adat memiliki hak dan kewenangan untuk menerima dan melayani warganya atau bahkan tamu yang datang dengan berbagai keperluan.

Hampir setiap hari, ketua adat menerima kunjungan dari jamaahnya, lengkap dengan segala permasalahan dan harapan mereka. Kunjungan tersebut mencapai puncaknya, pada acara seren taun nampa taun. Dengan penuh kesabaran dan keikhlasan, dia menerima kedatangan mereka. Dia juga akan memberikan apa yang diinginkan jamaah, selama itu dipandang akan mendatangkan keberkahan bagi yang bersangkutan.

Jamaah yang datang mengunjungi ketua adat, seringkali membawa buah tangan sebagai salah satu wujud kecintaan dan bakti mereka kepada dia. Ketika pulang pun, mereka tidak hanya sekadar mengucapkan terima kasih. Banyak di antaranya yang memberi sesuatu, baik berupa materi maupun janji. Materi yang diberikan umumnya berupa uang, yang besarannya bergantung pada kemampuan mereka. Meskipun demikian, hal tersebut bukanlah suatu keharusan. Selain itu, ada juga yang memberikan janji untuk berpartisipasi dan memberikan sesuatu kelak, ketika akan diselenggarakan kegiatan adat yang cukup besar, seperti upacara seren taun nampa taun.

Uang pemberian jamaah, bukan semata-mata untuk keperluan ketua adat. Pada saatnya nanti, sebagian besar dari uang tersebut akan kembali lagi kepada jamaah. Uang tersebut akan digunakan untuk mendanai berbagai kegiatan adat, tentu saja tanpa mengesampingkan partisipasi jamaah. Beberapa kegiatan itu di antaranya upacara seren taun nampa taun, mauludan, kerja bakti, dan membantu warga yang kekurangan.

\section{2) Memimpin Kegiatan Adat}

Hak dan kewenangan ketua adat lainnya adalah memimpin setiap penyelenggaraan kegiatan adat di Giri Jaya Padepokan. Kegiatan adat adalah semua aktivitas yang dilakukan untuk memenuhi satu tujuan tertentu, dilakukan secara turun temurun, dan senantiasa berhubungan dengan entitas leluhur warga Giri Jaya Padepokan. Dalam hal ini, ketua adat berhak memimpin kegitan tersebut, karena hanya dia yang memiliki kewenangan untuk berkomunikasi dengan leluhurnya.

Cukup banyak kegiatan adat yang dilaksanakan di wilayah tersebut, baik yang bersifat individu maupun komunal. Kegiatan adat yang di- 
selenggarakan secara individu di antaranya bersaji setiap malam Senin dan malam Jumat; dan menyelenggarakan upacara daur hidup, seperti perkawinan, kelahiran, tujuh bulanan, atau khitanan. Adapun kegiatan adat yang bersifat komunal antara lain upacara seren taun nampa taun, muludan, dan malam Jumat Kliwonan.

Pada kegiatan adat yang bersifat komunal, secara otomatis ketua adat akan bertindak sebagai pemimpinnya. Dia bertanggung jawab atas kelancaran kegiatan tersebut sepenuhnya, termasuk di dalamnya urusan pendanaan. Meskipun demikian, partisipasi warga Giri Jaya Padepokan juga tidak sedikit. Mereka senantiasa bergotong-royong dan bekerja sama di semua lini untuk kelancaran kegiatan tersebut.

Seorang ketua adat jarang sekali sampai tak bisa memimpin kegiatan adat, terutama pada acara besar seperti upacara seren taun nampa taun. Kalau pun tidak bisa, pasti ada alasan kuat yang mendasarinya, sakit yang benarbenar parah misalnya. Jika berhalangan seperti itu, dia akan menunjuk seseorang dari jajaran sesepuh adat untuk mewakilinya

Hak ketua adat memimpin kegiatan adat yang bersifat komunal memang tampak jelas. Berbeda halnya dengan kegiatan adat yang dilaksanakan secara individu, yang sepenuhnya berada di bawah kendali individu tersebut. Meskipun demikian, kondisi tersebut bukan berarti menghilangkan hak seorang ketua adat untuk memimpin kegiatan adat. Tetap ada ritual-ritual tertentu dari kegiatan adat tersebut yang memang menjadi haknya. Hal itu biasanya terkait dengan ritual memohon restu kepada leluhur. Untuk keperluan tersebut, penyelenggara kegiatan biasanya akan mengundang ketua adat secara khusus untuk menyerahkan apa yang menjadi haknya.

\section{3). Mengangkat Jabatan Para Sesepuh}

Tugas dan kewajiban seorang ketua adat tidak dapat dikatakan sedikit dalam memimpin warga Giri Jaya Padepokan. Oleh karena itu, dia tidak mungkin dapat bekerja sendiri. Dia memerlukan sejumlah orang yang dapat melaksanakan sebagian tugasnya. Untuk keperluan tersebut, dia memiliki hak dan kewengan penuh untuk mengangkat siapa saja yang akan membantunya. Dalam hal ini, dia harus mendelegasikan sebagian tugasnya kepada orang-orang yang menjadi kepercayaannya.

Pada dasarnya, setiap warga Giri Jaya Padepokan memiliki kesempatan masuk dalam jajaran sesepuh adat. Namun, tidak setiap orang memiliki kemampuan dan kapasitas yang sesuai dengan apa yang dibutuhkan oleh ketua adat. Siapapun dapat menduduki jabatan sesepuh di Giri Jaya Padepokan, asal memenuhi kriteria yang tepat untuk menduduki jabatan tersebut.

\section{Sesepuh Adat}

Setelah ketua adat, kedudukan berikutnya yang terdapat dalam struktur lembaga adat adalah sesepuh adat. Mereka terdiri atas sejumlah orang yang memiliki pengetahuan mendalam tentang adat istiadat Giri Jaya Padepokan. Selain itu, mereka menguasai bidang-bidang tertentu sebagai kelebihannya dibandingkan dengan warga Giri Jaya Padepokan lain pada umumnya. Kapasitas seperti itulah 
yang membuat seseorang diangkat dan dimasukkan ke dalam jajaran sesepuh adat.

Karena jabatan sesepuh adat diangkat oleh ketua adat, kedudukannya pun berada di bawah ketua adat. Mereka menerima pendelegasian tugas dari ketua adat, dan harus mempertanggung jawabkan pelaksanaan tugasnya kepada ketua adat pula. Masa berlaku jabatan tersebut biasanya berjalan seumur hidup. Kecuali karena alasan khusus, sakit atau melakukan perbuatan tercela misalnya, jabatan tersebut dapat dihentikan. Penggantinya, biasanya tidak akan jauhjauh, tetap berasal dari keluarga yang bersangkutan.

Seperti halnya jabatan ketua adat, jabatan sesepuh adat pun seolaholah diturunkan secara generasional. Kemungkinan besar hal itu terkait dengan proses pengkaderan yang berlangsung secara alami dalam keluarga. Karena terbiasa melihat atau bahkan terlibat dalam tugas yang dilaksanakan orang tuanya sebagai sesepuh adat, secara otomatis keturunannya pun akan memahaminya. Jabatanjabatan adat yang terdapat dalam jajaran sesepuh adat di Giri Jaya Padepokan adalah sebagai berikut:

\section{a. Wakil Ketua Adat}

Wakil ketua adat Giri Jaya Padepokan hanya ada satu orang. Seorang wakil ketua adat harus memiliki sifat jujur, benar dalam bersikap, luas pengetahuan umumnya, dan mendalam pula penguasaan tentang adat istiadat Giri Jaya Padepokan. Dia merupakan tangan kanan ketua adat yang mengurus segala urusan; juga sebagai penyambung lidah ketua adat kepada warganya; dan menerima tamu (bukan jamaah) yang datang untuk menemui ketua adat. Melihat tugasnya yang begitu strategis, kedudukan wakil ketua adat tampak lebih istimewa dibandingkan dengan sesepuh adat yang lainnya.

Seorang wakil ketua adat juga bertindak sebagai ketua jaga baya 'penjaga keamanan masyarakat', yang bertugas menjaga keamanan Giri Jaya Padepokan dari gangguan pencuri, kebakaran, musibah sakit, yang akan melahirkan, dan tamu yang datang tengah malam. Anggota jaga baya terdiri atas perwakilan dari setiap rumah yang disertakan untuk menjaga lingkungan Giri jaya Padepokan. Tidak kurang dari tujuh orang bertugas untuk setiap malamnya. Mereka berkeliling kampung dari pukul 20.00 WIB sampai dengan pukul 04.00 WIB. Sementara itu ketua jaga baya biasa mengontrol sampai pukul $24.00 \mathrm{WIB}$.

\section{b. Juru Kunci}

Juru kunci di Giri Jaya Padepokan hanya ada satu orang. Seorang juru kunci harus memiliki kecocokan batin dengan pekerjaannya. Dia harus ikhlas dalam melakukan pekerjaannya. Yang lebih penting lagi, dia harus mendapat waris dari karuhun 'leluhur'. Artinya, dia mendapat restu dari leluhur sehingga diberi kemampuan untuk menjalankan tugas sebagai juru kunci. Jika semua persyaratan tersebut terpenuhi, pekerjaan menjadi juru kunci akan mendatangkan berkah selamanya bagi jamaah juga dirinya.

Tugas juru kuci adalah mengantar tamu, baik anggota maupun bukan anggota jamaah yang akan berziarah ke pasarean Giri Jaya. Selain itu, dia juga harus menjaga kebersihan 
lingkungan pasarean. Di dalam pasarean ada beberapa makam, yang terdiri atas makam Eyang Abu Soleh, yang merupakan karuhun asal usul masyarakat Giri Jaya; makan Eyang Wiratmaja dan ketiga anaknya, yakni Ama Aom, Ama Dadang, dan Ama Entang. Selain itu, ada makam Eyang Muhamad Gentar dan Embah Yus.

\section{c. Tokoh Seni}

Kedudukan kesenian dalam kehidupan masyarakat Giri Jaya Padepokan memang khas. Beberapa jenis kesenian, khususnya wayang golek, dikuasai oleh ketua adat dari generasi pertama sampai sekarang. Ketua adat Giri Jaya Padepokan begitu memperhatikan aspek kesenian, terutama kesenian tradisional. Hal itu dilakukan sebagai wujud penghormatan kepada leluhurnya, terutama para ketua adat sebelumnya yang juga sama-sama mencintai kesenian. Dalam hal ini, leluhur telah mewariskan nilai-nilai keindahan melalui kesenian tradisional yang masih dilestarikan oleh keturunannya sampai sekarang. Mereka memang dikenal piawai dalam berkesenian, khususnya sebagai seniman dalang. Oleh karena itu, melestarikan kesenian tradisional merupakan salah satu amanat leluhur yang wajib dilaksanakan oleh setiap ketua adat secara turun temurun. Ketua adat sekarang pun mahir mendalang dan memainkan instrumen kesenian Sunda lainnya.

Masyarakat Giri Jaya Padepokan pun begitu mencintai kesenian tradisional. Ada yang menjadi pelaku seni, dan ada pula yang bertindak sebagai apresiator seni. Oleh karena itu, kesenian merupakan bagian yang tidak terpisahkan dari kehidupan masyarakat
Giri Jaya Padepokan. Kesenian ada dalam kehidupan sehari-hari mereka, dan hadir pula menyertai aktivitas adat. Jenis kesenian yang dipelihara di tempat tersebut adalah degungan, wayang golek, kecapi, pongdut, kendang penca, dan jaipongan.

Kesenian tradisional di Giri Jaya Padepokan terjaga dengan baik melalui keberadaan tokoh seni yang berjumlah empat orang dalam jajaran sesepuh adat di Giri Jaya Padepokan. Mereka semuanya laki-laki, sudah cukup umur, dan tentu saja menguasi sejumlah kesenian tradisional. Jabatan sebagai tokoh seni biasanya juga didapat secara turun temurun, dengan masa jabatan yang berlaku sepanjang mereka masih mampu berkesenian. Di pundak mereka, eksistensi kesenian tradisional di Giri Jaya Padepokan dipertaruhkan. Oleh karena itu, tugas yang diemban oleh para tokoh seni tidak mudah. Meskipun demikian, mereka tulus menerima tugas tersebut karena kecintaan mereka terhadap seni, dan tentunya sebagai wujud bakti kepada ketua adat dan leluhur mereka.

Ada beberapa tugas penting yang harus dilakukan oleh para tokoh seni. Pertama, mereka mendapat tugas untuk menjadi pengelola kesenian yang ada di Giri Jaya Padepokan. Itu artinya, mereka harus menghidupkan kesenian yang ada di wilayah Giri Jaya Padepokan, baik untuk kepentingan adat juga untuk kepentingan yang sifatnya komersil. Kedua, mereka mendapat tugas untuk menjadi koordinator seniman atau pelaku seni yang ada di wilayah tersebut. artinya, mereka harus mendengarkan aspirasi yang datang dari para pelaku seni di wilayah tersebut. Ketiga, mereka mendapat tugas untuk menjadi pembina 
generasi muda yang memiliki bakat dan minat untuk menggeluti kesenian tradisional. Itu artinya, mereka harus meluangkan waktu untuk melakukan regenerasi seniman di Giri Jaya Padepokan.

Ada beragam jenis kesenian tradisional yang dilestrarikan oleh ketua adat Giri Jaya Padepokan dan warganya. Beberapa di antaranya kesenian wayang golek, degung, jaipongan, kecapi suling, dan penca. Sebagai sarana pendukungnya disediakan berbagai alat kesenian, bahkan hingga sound systemnya. Peralatan tersebut disimpan di satu ruangan yang sekaligus juga merupakan tempat latihan berkesenian. Sementara itu, beragam instrumen kesenian tinggalan leluhur ditempatkan di paseban atau pendopo.

Warga komunitas adat Giri Jaya Padepokan yang ingin mempelajari jenis-jenis kesenian tradisional yang disebutkan tadi, bisa datang ke tempat latihan. Mereka bebas berlatih di sana, tanpa dipungut bayaran. Mereka mengikuti jadwal latihan yang berlangsung setelah Magrib hingga menjelang Isa. Sementara itu, orang dewasa melakukan hal yang sama setelah shalat Isya sampai dengan maksimal menjelang shalat Subuh, bahkan tak jarang menggunakan sound system sebagai pengeras suara.

Bayangkanlah! Malam hari di kaki Gunung Salak yang dingin menggigit, terdengar alunan irama gamelan mengiringi suara merdu seorang penembang. Sementara itu, di sana sini terdengar pula gemericik air mengalir yang melimpah di antara keheningan malam. Itulah gambaran suasana harmoni yang sering tercipta pada malam hari hingga dini hari di Giri Jaya Padepokan.

Warga komunitas adat yang mengikuti latihan kesenian, tentu ingin memperlihatkan keahliannya di depan orang banyak atau manggung. Kesempatan itu selalu ada, dari acara yang sederhana hingga acara yang besar layaknya pesta kampung. Pada kesempatan yang sangat sederhana misalnya, kesenian kecapi suling sering menemani kegiatan kumpul-kumpul kecil ketua adat dengan para sesepuh atau tamunya; pada acara yang besar seperti upacara seren taun nampa taun, semua jens kesenian yang ada di Giri Jaya Padepokan akan ditampilkan untuk menghibur keluarga besar Giri Jaya Padepokan; dan secara komersil, kelompok kesenian yang sudah mapan sering mendapat undangan, tampil pada acara kendurian perorangan, organisasi, atau instansi.

\section{d. Tokoh Agama}

Seluruh warga masyarakat Giri Jaya Padepokan memeluk agama Islam. Beberapa di antara mereka memiliki pengetahuan yang luas dan mendalam tentang agama Islam. Orang-orang tersebut biasanya diberi keikhlasan untuk berbagi ilmu agama dengan warga masyarakat lainnya. Karena berilmu seperti itu, orang tersebut dikatagorikan sebagai tokoh agama, dengan panggilan khususnya $u$ stad.

Keberadaan toloh agama dipandang sangat penting oleh ketua adat sebagai penjaga aqidah masyarakat. Oleh karena itu, tokoh agama ditempatkan ke dalam jajaran sesepuh adat di wilayah Giri Jaya Padepokan. Ada dua orang laki-laki yang menempati kedudukan sebagai tokoh agama dalam jajaran sesepuh 
adat. Keduanya mendapat tugas untuk mengajarkan agama kepada anak-anak; memimpin kelompok pengajian ibuibu; mengisi kegiatan sehari-hari di masjid dan pada saat Jumatan; dan memimpin doa pada acara-acara adat. Ada kalanya, warga masyarakat juga menanyakan hari baik untuk melaksanakan suatu aktivitas penting.

\section{e. Amil}

Amil adalah orang yang mendapat tugas untuk menikahkan pasangan calon pengantin, mengurusi jenazah, membagi waris, dan menerima pengaduan masalah rumah tangga warga. Pada dasarnya, tugas untuk menikahkan calon pengantin datang dari Kantor Urusan Agama. Meskipun demikian, kedudukannya sangat penting bagi kelangsungan hidup masyarakat Giri Jaya Padepokan. Oleh karena itu, dia termasuk ke dalam jajaran sesepuh adat di wilayah tersebut.

\section{f. Pelaksana Ritual Adat}

Pelaksana ritual adat adalah orang yang membantu ketua adat melaksanakan berbagai ritual adat di wilayah Giri Jaya Padepokan. Ada sekitar 7 orang yang termasuk dalam kelompok pelaksana ritual adat. Mereka semua laki-laki, sudah berumur, dan dipastikan menguasai adat istiadat Giri Jaya Padepokan. Dalam setiap pelaksanaan aktivitas adat, mereka senantiasa terlibat di dalamnya. Aktivitas adat tersebut di antaranya upacara-upacara adat, kendurian, juga kematian. Mereka menyiapkan segala sesuatu yang terkait dengan pelaksanaan ritual adat dari awal hingga selesai. Selain itu, mereka juga kerap diminta warga meng- upayakan kesembuhan atas penyakit yang dideritanya.

\section{g. Koordinator Warga}

Koordinator warga adalah seseorang yang memiliki kemampuan menggerakkan dan mengatur warga masyarakat untuk melakukan sesuatu bagi kepentingan bersama, seperti kerja bakti, gotong royong, dan kegiatan sosial. Oleh karena, seorang koordinator warga biasanya memiliki sifat ramah, berwibawa, dan dikenal banyak orang. Karakter itu membuat warga tergerak untuk mengikuti ajakannya.

\section{h. Tokoh Masyarakat}

Pengikut adat istiadat Giri Jaya Padepokan tidak terbatas pada masyarakat yang tinggal di wilayah Giri Jaya Padepokan. Banyak juga di antaranya yang menetap di luar wilayah itu. Oleh karena itu, ketua adat perlu menunjuk orang yang dapat mewakili kedudukannya di kampung lain yang ada warganya. Orang yang memimpin keluarga besar Giri Jaya Padepokan di luar wilayah Giri Jaya Padepokan disebut tokoh masyarakat. Dia merupakan kepanjangan tangan ketua adat di luar wilayah Giri Jaya Padepokan. Jumlah tokoh masyarakat, tentu saja lebih dari satu orang.

\section{i. Paraji}

Paraji merupakan satu-satunya wanita yang ada dalam jajaran sesepuh adat. Kedudukan paraji dalam kehidupan masyarakat Giri Jaya Padepokan sangat penting, terutama bagi wanita dan anak-anak. Tugas utama dia adalah membantu merawat wanita yang sedang hamil, membantu persalinannya, serta melaksanakan 
ritual adat yang menyertai kehamilan dan persalinan seorang ibu hamil. Selain itu, dia juga menangani kesehatan bayi dan anak-anak secara tradisional.

\section{Jamaah atau Keluarga Besar Giri Jaya Padepokan}

Setelah ketua adat dan para sesepuh, masih tersisa satu lagi kedudukan yang terdapat dalam struktur lembaga adat di Giri Jaya Padepokan. Kedudukan itu diberi nama keluarga besar Giri Jaya Padepokan atau sering disebut jamaah oleh ketua adat. Mereka adalah pendukung atau semua orang yang menginduk pada adat istiadat Giri Jaya Padepokan. Jumlah anggota jamaah secara keseluruhan kurang lebih mencapai lima ribuan. Angka tersebut diambil dari perkiraan warga yang hadir sebagai peserta dalam kegiatan upacara seren taun nampa taun. Mereka terdiri atas keluarga besar keturunan Eyang Abu Sholih, dan yang bukan berasal dari keturunan Eyang Abu sholih.

Keturunan Eyang Abu Sholih dan keluarga besarnya tentu saja merupakan pendukung utama kelangsungan adat istiadat Giri Jaya Padepokan. Mereka terdiri atas orangorang yang memiliki hubungan darah atau ikatan biologis dengan cikal bakal Giri Jaya Padepokan; juga orang-orang yang terikat oleh hubungan sosiologis dengan anggota dari keturunan Eyang Abu Sholih, seperti hubungan pernikahan. Adapun di luar keturunan Eyang Abu Sholih, banyak juga yang mengikuti adat istiadat Giri Jaya Padepokan. Mereka memutuskan menjadi pengikutnya, karena hal itu telah memberikan keberkahan dan kesejahteraan dalam kehidupan mereka.

Sebagian anggota jamaah tinggal di dalam wilayah adat Giri Jaya Padepokan, yakni di Giri Jaya I atau Giri Jaya Pusat, Giri Jaya II atau Giri Jaya Tengah, dan Giri Jaya III atau Giri Jaya Hilir. Tidak sedikit pula anggota jamaah yang menetap di kampungkampung sekitar, bahkan meluas ke Kabupaten Bekasi, Lebak, Kabupaten Tangerang, Kabupaten/Kota Bogor, Serang, dan Kota Sukabumi.

Seluruh jamaah, baik yang tinggal di dalam maupun di luar wilayah adat, memiliki kewajiban untuk patuh kepada pimpinan mereka, yakni ketua adat. Kepatuhan kepada dia sama dengan menghormati leluhur Giri Jaya Padepokan, karena hakikatnya dia merupakan perwakilan leluhur di bumi. Dalam konteks itulah, jamaah harus berbakti, menghormati, mendengarkan nasihat, mengikuti perintah, dan menjauhi segala larangannya. Semua itu tentu dalam konteks yang berhubungan dengan adat istiadat Giri Jaya Padepokan, yang memang digawangi oleh ketua adat.

Ketua adat pun mengharapkan agar jamaah senantiasa memegang teguh apa yang telah diwariskan leluhurnya. Setiap langkah mereka dalam kehidupan sehari-hari, selalu mengacu pada adat itiadat Giri Jaya Padepokan. Keteguhan seperti itu dipercaya akan mendatangkan keberkahan bagi mereka, karena segala sesuatunya mendapat restu ketua adat. Restu dari dia sama dengan mendapat restu dari leluhur, karena dia merupakan perwakilan leluhur di dunia. Sebaliknya, dia akan merasa prihatin jika ada jamaahnya yang meninggalkan 
atau jauh dari adat istiadat Giri Jaya Padepokan. Dia khawatir hal itu akan membuat hidup jamaah senantiasa jauh dari segala keberkahan.

Jamaah yang tinggal berdekatan dengan pusat Giri Jaya Padepokan, terutama yang berada di wilayah adat, lebih memungkinkan untuk mengekspresikan adat istiadat dalam berbagai aspek kehidupan secara total. Setiap saat mereka bisa datang meminta berkah kepada ketua adat atas segala niat untuk melakukan aktivitas penting. Mereka dapat mengikuti dan melaksanakan semua aktivitas adat yang dilakukan di Giri Jaya Padepokan. Dengan demikian, secara berkesinambungan mereka senantiasa berada di lingkungan sosial yang memelihara adat istiadat Giri Jaya Padepokan.

Kesadaran itu akan selalu terjaga karena ada pengendalian dan pengawasan langsung dari ketua adat beserta jajarannya. Sekali saja jamaah melanggar aturan adat, mereka harus berhadapan langsung dengan ketua adat dan lingkungan sosialnya. Mereka akan mendapat sanksi sosial dari lingkungan masyarakatnya, digunjingkan misalnya. Selain itu, mereka dipastikan mendapat teguran dari pemimpin adat agar kembali mematuhi adat istiadat setempat.

Berbeda halnya dengan jamaah yang berada jauh dari pusat Giri Jaya Padepokan, cukup sulit untuk berperilaku total seperti itu. Secara individu, mereka merasa sebagai bagian dari jamaah Giri Jaya Padepokan. Jika memungkinkan, dia akan berupaya melakukan komunikasi dengan ketua adat agar mendapat berkah dalam kehidupannya. Secara sosial, mereka memiliki keterbatasan untuk senantiasa terlibat dalam semua aktivitas yang bernuansa adat. Sekalipun begitu, mereka tetap berupaya untuk berpartisipasi di dalamnya, baik dengan memberi sumbangan. atau terlibat langsung dalm kegiatan tersebut. Paling tidak, ada satu kesempatan yang sangat jarang dilewatkan oleh mereka, yakni mengikuti upacara seren taun nampa taun.

Ribuan anggota jamaah datang ke acara yang paling besar di Giri Jaya Padepokan. Kedatangan mereka untuk mengekspresikan beberapa hal penting, di antaranya mereka ingin membuktikan dirinya sebagai bagian dari jamaah Giri Jaya Padepokan; mereka juga mengharapkan berkah yang melimpah dari upacara tersebut; mereka memanfaatkan kesempatan tersebut untuk saling bersilaturahim satu sama lainnya; dan mereka juga ingin menunjukkan rasa baktinya kepada ketua adat dan leluhurnya.

\section{PENUTUP}

Aturan adat yang mendasari organisasi sosial pada masyarakat Giri Jaya Padepokan merupakan warisan leluhur yang terpranatakan dalam satu lembaga adat. Tidak ada nama khusus untuk lembaga adat tersebut. Keberadaan lembaga adat dipandang masih relevan mengatur tata kehidupan masyarakat Giri Jaya Padepokan sampai saat ini. Lembaga adat itu mengatur kedudukan seseorang dalam struktur masyarakat Giri Jaya Padepokan.

Dalam struktur lembaga adat, secara hierarkis ditempatkan kedudukan seseorang dalam kehidupan masyarakat Giri Jaya Padepokan. 
Kedudukan yang paling tinggi ditempati oleh seorang ketua adat. Dia adalah pemimpin Giri Jaya Padepokan, dengan segala kewajiban yang harus dilaksanakannya serta hak-hak yang akan diterimanya. Kedudukan berikutnya ditempati oleh jajaran sesepuh adat, yang terdiri atas sejumlah orang tertentu. Mereka diberi tugas khusus oleh ketua adat, yang berbeda satu sama lainnya. Para sesepuh itu merupakan orang-orang pilihan yang akan membantu ketua adat dalam menjalankan tugasnya. Kedudukan yang paling rendah ditempati oleh keluarga besar Giri Jaya Padepokan, yang disebut jamaah. Yang termasuk dalam jamaah adalah seluruh warga yang menginduk pada adat istiadat Giri Jaya Padepokan. Di antara mereka, ada yang tinggal di wilayah Giri Jaya Padepokan, dan ada juga yang menetap di luar wilayah itu.

Masyarakat Giri Jaya Padepokan merupakan aset yang begitu bernilai bagi masyarakat juga pemerintah Jawa Barat, khususnya Kabupaten
Sukabumi. Mereka merupakan salah satu komunitas adat di Kabupaten Sukabumi yang memiliki keunikan tersendiri, yakni melestarikan budaya Sunda yang diwarnai budaya Jawa. Oleh karena itu, keberadaan mereka perlu mendapat perhatian dari berbagai pihak, termasuk pemerintah agar senantiasa mendapat ruang untuk mengekspresikan adat istiadat mereka.

\section{DAFTAR PUSTAKA}

Sanit, Arbit. 1984. Sistem Politik Indonesia. Jakarta: Rajawali.

Shm., Suhandi. 1991.

Pola Hidup Masyarakat Indonesia. Bandung: Jurusan Antropologi UNPAD

Soekanto, Soerjono.1982. Sosiologi Suatu Pengantar. Jakarta: Rajawali .1983.

Beberapa Teori Sosiologi tentang Struktur Masyarakat. Jakarta: Rajawali. 